\title{
23. SPECTRAL GAMMA-RAY LOGS IN RELATION TO CLAY MINERALOGY AND SEQUENCE STRATIGRAPHY, CENOZOIC OF THE ATLANTIC MARGIN, OFFSHORE NEW JERSEY ${ }^{1}$
}

\author{
Stephen P. Hesselbo ${ }^{2}$
}

\begin{abstract}
The spectral gamma-ray logs for all sites drilled on Ocean Drilling Program Leg 150 can be subdivided into four spectral gamma-ray units characterized by distinct patterns of total gamma radiation; $\mathrm{Th}, \mathrm{U}$, and $\mathrm{K}$ content; and $\mathrm{Th} / \mathrm{K}$ and $\mathrm{Th} / \mathrm{U}$ ratios. These units (A-D) are of genetic significance in that they correspond to the major elements of the large-scale, "second-order" sequence stratigraphic architecture of the Atlantic continental margin, offshore New Jersey.

Changes in the $\mathrm{Th} / \mathrm{K}$ ratios throughout the succession can be explained by changing relative proportions of detrital clay minerals, particularly illite, mixed-layer illite-smectite, smectite, and kaolinite, except over intervals where glauconitization has been a significant process. Changes in $\mathrm{Th} / \mathrm{K}$ ratios due to changes in detrital clay minerals do not in this case closely reflect distance from shoreline, but instead register mainly changes in transportation mechanisms and source area climate or topography.

Glauconitic intervals show variable $\mathrm{Th}, \mathrm{U}$, and $\mathrm{K}$ content but in general have very low Th values. Variable $\mathrm{U}$ and $\mathrm{K}$ content means that the same glauconitic horizon when traced downslope may change from a total gamma-ray low to a total gamma-ray high. Total gamma-ray peaks are likely to be misleading indicators of maximum flooding surfaces in offshore settings containing significant quantities of glauconitic minerals.
\end{abstract}

\section{INTRODUCTION}

A log of the total natural gamma radiation from a formation has long been recognized as one of the most useful tools for subsurface correlation (e.g., summarized in Whittaker et al., 1985). More recently, total gamma-ray logs have been employed in sequence stratigraphic analysis, principally on the basis that gamma-ray peaks correspond to lithologic successions indicative of maximum flooding (e.g., Milton et al., 1990; Vail et al., 1991; Armentrout et al., 1993). Also, with the advent of natural gamma-ray spectrometry, many workers have attempted to relate calculated $\mathrm{Th}, \mathrm{U}$, and $\mathrm{K}$ abundances (the common elements containing gamma-ray emitting isotopes or having them in their decay series) to lithologic factors such as clay mineralogy (Quirein et al., 1982) or paleoenvironmental conditions such as bottom-water oxygenation (Adams and Weaver, 1958; Myers and Wignall, 1987; Wignall and Myers, 1988), both from subsurface and outcrop settings. A related strand of research has explored the possible paleogeographic and paleoclimatic significance of variations in the ratios of $\mathrm{Th}, \mathrm{U}$, and $\mathrm{K}$ in marine facies, whether directly related to clay mineral composition or not (Adams and Weaver, 1958; Myers and Wignall, 1987; Myers, 1989; Parkinson, 1994, 1996).

The combined seismic and downhole data sets gathered for Leg 150 allow a critical assessment of both the more routine and more innovative uses of gamma-ray logs in sequence stratigraphy as applied to distal marine environments. Thus, the principal aims of this paper are (1) to summarize the relationship between spectral gamma-ray logs, gross lithology and stratigraphic architecture for all sites drilled on Leg 150, and (2) to critically assess the use of spectral gamma-ray logs in sequence stratigraphy, including their possible application as proximal-distal facies indicators.

Mountain, G.S., Miller, K.G., Blum, P., Poag, C.W., and Twichell, D.C. (Eds.) 1996. Proc. ODP, Sci. Results, 150: College Station, TX (Ocean Drilling Program).

'Department of Earth Sciences, University of Oxford, Parks Road, Oxford OX1 3PR, United Kingdom. stephess@earth.ox.ac.uk
For a full discussion of the theoretical basis of gamma-ray spectrometry, refer to the general accounts of the Borehole Research Group (1990) and to Doveton (1994). For a consideration of Leg 150 shipboard natural gamma-ray measurement refer to Hoppie, Blum, et al. (1994). In brief, decay of naturally occurring ${ }^{40} \mathrm{~K},{ }^{232} \mathrm{Th}$ series, and ${ }^{238} \mathrm{U}$ series within a rock produces a spectrum of gamma-ray energies that allow calculation of original elemental abundances. In this paper gamma radioactivity is displayed in two curves, both in Gamma-ray American Petroleum Institute (GAPI) units. The standard gamma-ray (SGR) curve records the total gamma radiation from all sources whereas the computed gamma-ray (CGR) curve results from subtraction of the U contribution from the SGR curve. The CGR curve is generally used as a "shale indicator" on the basis that Th and $\mathrm{K}$ are predominantly sited on or within clay minerals. Calculated content of Th and $\mathrm{U}$ is expressed in parts per million, and $\mathrm{K}$ is given in percent.

It is important to understand the mineralogical preferences of Th, $\mathrm{U}$, and $\mathrm{K}$ in relation to weathering, transport, deposition, and diagenesis in order sensibly to interpret patterns in their content through the succession. These aspects are well summarized by Serra (1979), Myers and Wignall (1987), Rider (1991), and Doveton (1994). Potassium is an element occurring within the structure of many common detrital minerals. Potentially, the most important of these in the context of Leg 150 are certain clays, especially illite, mixed-layer illite/smectite, and glauconitic minerals. Other clays, particularly kaolinite, smectite, and chlorite, may contain negligible quantities of potassium. K-feldspar may also be important within some sandy intervals in the Pleistocene sections, but otherwise generally occurs in very small quantities. Thorium is effectively insoluble in natural waters (Langmuir and Herman, 1980) and may contribute to the radioactivity of a rock either as a structural component of resistate heavy minerals, or adsorbed onto the surfaces of clay minerals, particularly those formed under strongly leaching soil conditions such as kaolinite and smectite. Uranium may also occur associated with the detrital clay fraction but, in addition, is commonly dissolved in sea and river water. From solution, uranium is fixed in sediments by precipitation in reducing environments (Adams and Weaver, 1958; Swanson, 1960). The precise mechanism by which this takes place is still uncertain, although it may involve sorption by organic matter and/or phosphate 
(Koczy, 1956; Kochenov et al., 1977; Myers and Wignall, 1987; Wignall and Myers, 1988). The requirement for reducing conditions for $\mathrm{U}$ fixation means that there is a general correlation between uranium content and Total Organic Carbon (TOC) in sediments (e.g., Bjørlykke et al., 1975).

\section{SPECTRAL GAMMA-RAY CHARACTERISTICS OF THE SUCCESSION}

\section{Spectral Gamma-ray Units}

Good quality gamma-ray logs were recorded for about $65 \%$ of the drilled intervals on Leg 150 (Figs. 1, 2). In this study the log runs through casing or in bad holes (Hole 903C) have not been used. Data from 902D are used with caution because hole conditions above 500 mbsf were also poor. Detailed accounts of logging conditions can be found in the appropriate site chapters of Mountain, Miller, Blum, et al. (1994). All data used in this study were corrected for borehole diameter and drilling fluid by the Borehole Research Group, LamontDoherty Geological Observatory.

In general, the logs at each site characterize different aspects of the overall succession (Fig. 2). Logs for the Pleistocene section of acceptable quality were obtained only at Site 903 , the thickest of the slope sites, and at Site 905 on the rise. The uppermost Miocene was also logged at Sites 903 and 905, but it has been eroded from the lower slope sites. Site 905 is the only site with a significant Pliocene record. The log for Site 906 records mainly the middle/upper Miocene fill of a canyon-like feature (Mountain et al., this volume) together with a limited Eocene and Oligocene section below the canyon floor (Figs. 1, 2). Site 902 and Site 904 are the only sites with high quality spectral gamma-ray logs through coeval deposits of similar facies (upper Oligocene to upper Miocene), and these sites allow some consideration of downslope changes in log character. In addition, Site 904 provides a good record of the middle and upper Eocene pelagic section.

The spectral gamma-ray logs from the Cenozoic succession drilled on Leg 150 divide simply and unambiguously into four intervals characterized by contrasting $\mathrm{Th}, \mathrm{K}$, and $\mathrm{U}$ content and ratios (Table 1; Figs. 1-7). The boundaries between these intervals do not always correspond to the boundaries between lithologic units, nor do they always correspond to the boundaries of log units as defined in Mountain, Miller, Blum, et al. (1994). Therefore, an independent scheme has had to be adopted in this study: spectral gamma-ray Units A-D.

The stratigraphically highest unit (Unit A; Figs. 1-3, 5, 7) comprises gray silty clay, with coarse sand and mud pebbles, commonly emplaced by slump and debris flow processes. Unit A is characterized by moderate to high Th (4-9 ppm), moderate to low U (2-4 ppm), and moderate to high $\mathrm{K}(1 \%-2 \%)$. Consequently, ratios of $\mathrm{Th} / \mathrm{K} \times 10^{-4}$, referred to hereafter as simply $\mathrm{Th} / \mathrm{K}$ ratios, are moderate to low (3-5) and $\mathrm{Th} / \mathrm{U}$ ratios are moderate to high $(2-10)$. The fields of $\mathrm{Th} / \mathrm{K}$ against $\mathrm{Th} / \mathrm{U}$ are indistinguishable for Sites 903 and 905 (Fig. 7). The boundary between Units A and B at Site 903 coincides with the top of the highly attenuated Pliocene section and just above the inferred position of Reflector p6 (Fig. 3). The base of Unit A at Site 905 also coincides with the top of the Pliocene section, which in this case is more expanded (Fig. 5).

Unit B is represented by gray and brown silty clay with sandy debris flows and slumps. The upper part, seen only at Site 903 has several strongly glauconitic intervals. The spectral gamma-ray log of Unit B shows rather similar elemental compositions to that of Unit A, although with somewhat higher $\mathrm{Th} / \mathrm{K}$ ratios, which reflect overall slightly reduced potassium content: moderate to high Th $(4-10 \mathrm{ppm})$, moderate to low $\mathrm{U}(2-4 \mathrm{ppm})$, and moderate $\mathrm{K}(1 \%-2 \%)$. In the glauconitic sands, the Th content shows a marked decrease whereas the $\mathrm{K}$ content increases (Fig. 3). These values plot outside the main field indicated in Figure 7. In this same plot, the fields for Site 903 and Site 904 are indistinguishable. The field for Site 906 shows higher Th/K ratios, and the field for Site 905 shows lower $\mathrm{Th} / \mathrm{K}$ ratios, although the fields predominantly overlap.

The lithology of Unit C comprises diatomaceous and silty claystone and glauconitic sandstone. The Th, $\mathrm{K}$, and $\mathrm{U}$ compositions and ratios contrast greatly with those of the other three units (Figs. 4, 6, 7). The low $\mathrm{Th} / \mathrm{U}$ ratios result principally from moderate to high $\mathrm{U}$ content, although Th content is also locally low. Uranium content in particular shows considerable variation down dip (4-16 ppm at Site 906, 4-18 ppm at Site 902, and 2-7 ppm at Site 904). Unit C has highly variable ratios of $\mathrm{Th} / \mathrm{K}(1-12)$ and low ratios of $\mathrm{Th} / \mathrm{U}(0.4-2)$. Values of SGR are moderate to high, ranging from 40-180 GAPI. The boundary between Units C and D at Site 904 is coincident with the boundary between lithologic Units IV and V and lies between the inferred positions of Reflectors $\mathrm{m} 2$ and $\mathrm{m} 3$. At Site 902 the boundary appears stratigraphically lower, occurring within lithologic Unit V and between the inferred positions of Reflectors $\mathrm{m} 3$ and $\mathrm{m} 4$. Biostratigraphic evidence confirms that the geochemical facies change occurs later in the more seaward site, compatible with the progradational nature of sedimentation at that time.

The stratigraphically lowest interval (Unit D; Figs. 4, 7), which is dominantly a nannofossil chalk, has relatively high $\mathrm{Th} / \mathrm{K}$ ratios (412) and high $\mathrm{Th} / \mathrm{U}$ ratios (1-12). Values of SGR for this interval are low (10-40 GAPI). The high $\mathrm{Th} / \mathrm{K}$ and $\mathrm{Th} / \mathrm{U}$ ratios reflect the relative abundance of Th (despite its low to moderate absolute content; 2-4 ppm), particularly in the upper half of lithologic Unit VII, as would be expected from the somewhat argillaceous character. The elemental abundance and ratio values for this unit should be treated with some caution, given the generally low content of radioactive isotopes (cf. Glendron et al., 1988). The boundary between Units C and D is coincident with the boundary between lithologic Units VI and VII and the inferred position of Reflector 01 .

\section{Relationship of Spectral Gamma-ray Units to Depositional Geometry}

The spectral gamma-ray units of the slope sites, defined solely on the basis of their gamma-ray signatures, also correspond to major components of the large-scale stratigraphic geometries as defined by seismic reflection profiles (Fig. 1; Mountain et al., this volume). The boundary between Units D and C corresponds to a major lower Oligocene hiatus and a marked upward change in facies from predominantly pelagic deposition in the Eocene to hemipelagic deposition in the Oligocene. There is an abrupt increase in terrigenous detrital components at this boundary, notably the first substantial occurrence of quartz sand (data from smear slide observations reported in Mountain, Miller, Blum, et al., 1994).

The boundary between Units C and B coincides approximately with surface $\mathrm{m} 3$ into which deep canyon-like features are locally incised at Site 906 (Fig. 2) and elsewhere (in Houston Well 855-1; Greenlee et al., 1992). The boundary is marked in the logs by an abrupt upward increase in Th content, reflecting both increased terrigenous input and higher sedimentation rates. The spectral gammaray signature sheds light on an apparent down-dip diachroneity of facies, but it also provides a constraint on the erosional and depositional history of the canyon-like feature drilled at Site 906 (Mountain et al., this volume). The log signature of the lowest lithologic subunit of the canyon fill in Hole 906A belongs to Unit B and contrasts with Unit C into which the canyon is cut, indicating that the sediment source was not principally the wall of the canyon, but instead much of it corresponds in facies to sediment deposited well above Reflector $\mathrm{m} 4$ at Site 902. The close association in time of canyon formation and the deposition at the base of Unit B is probably not coincidental, since both can be interpreted in relation to increased sediment accumulation (and loading) as the toes of prograding clinoforms moved into the outer shelf area (Fig. 1).

The boundary between spectral gamma-ray Units B and A corresponds to the very reduced and incomplete Pliocene section (Fig. 2); no shelf clinoforms from that time are preserved in the area of the 

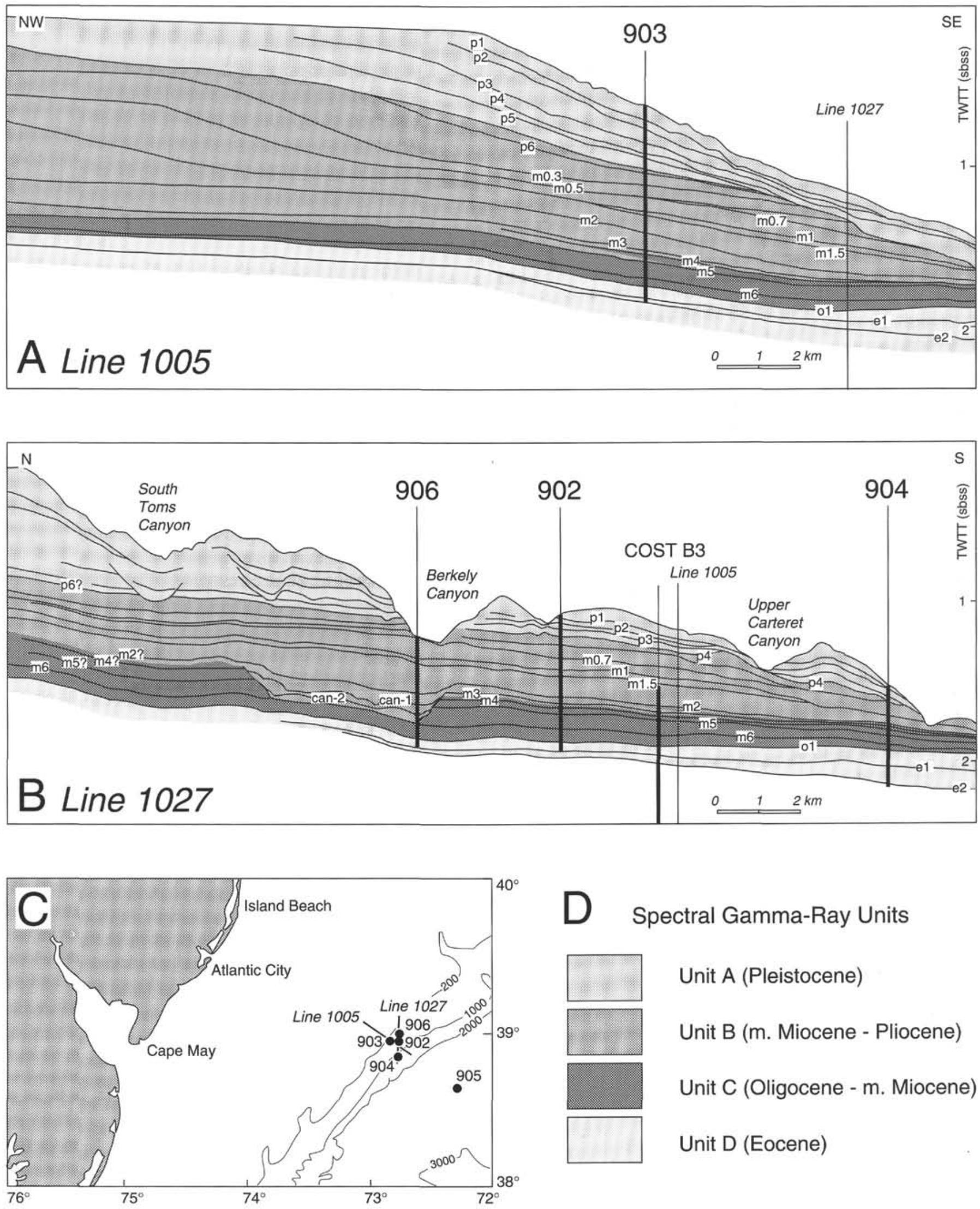

Unit A (Pleistocene)

Unit B (m. Miocene - Pliocene)

Unit C (Oligocene - m. Miocene)

Unit D (Eocene)

Figure 1. Large-scale stratal geometries defined on seismic reflection profiles and positions of all Leg 150 sites (line drawings from Mountain, Miller, Blum et al., 1994; thick lines indicate cored intervals). See text for discussion of spectral gamma-ray units. A. Line 1005. B. Line 1027. C. Location map (submarine contours in meters). D. Key to spectral gamma-ray units. 

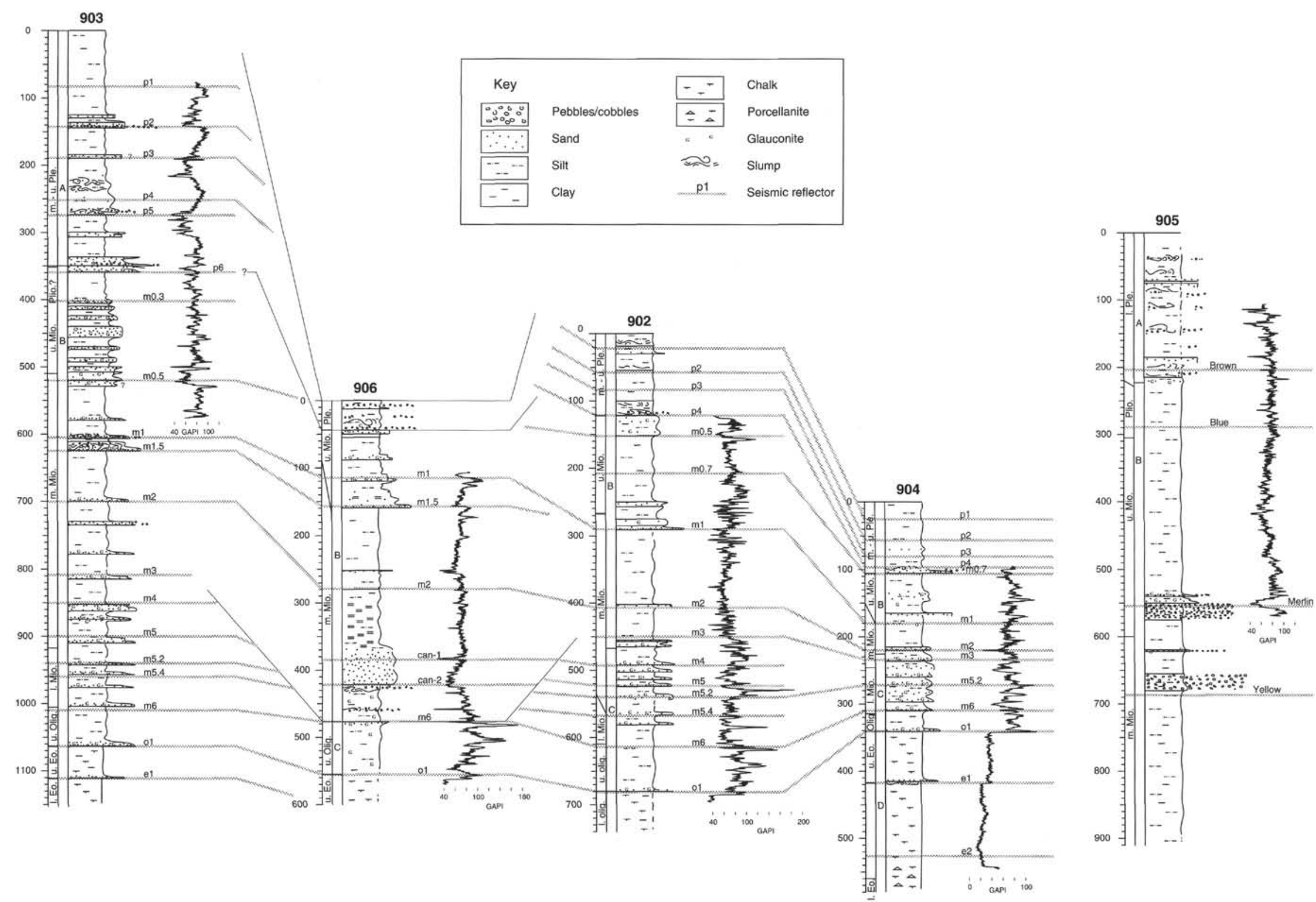

Figure 2. Total gamma-ray (SGR) logs for all intervals used in this study. Lithologic columns are generalized and are based on data from all holes at all Leg 150 sites as documented in Mountain, Miller, Blum, et al. (1994). Inferred positions of seismic reflectors are from G.S. Mountain (pers. comm., 1994). 
Table 1. Spectral gamma-ray units and their characteristics, Leg 150.

\begin{tabular}{lllllll}
\hline Unit & \multicolumn{1}{c}{ SGR } & Thorium & Uranium & Potassium & Th/K & Th/U \\
\hline A & Moderate & Moderate-high & Moderate-low & Moderate-high & Low & High \\
B & Moderate & Moderate-high & Moderate-low & Moderate & High & High \\
C & Moderate-high & Moderate & Moderate-high & Moderate & High and low & Low \\
D & Low & Low-moderate & Low & Low & High & High \\
\hline
\end{tabular}

Notes: SGR (GAPI): low $=<50$, moderate $=50-100$, and high $=>100$. Th or U $(\mathrm{ppm}):$ low $=<3$, moderate $=3-6$, and high $=>6 . \mathrm{K}(\%):$ low $=<1$, moderate $=1-2$, and high $=>2$. $\mathrm{Th} / \mathrm{K}$ : low $=<5$ and high $=>5$. Th/U: low $=<2$ and high $=>2$. Stratigraphic extent of units is shown in Figures $1-6$.

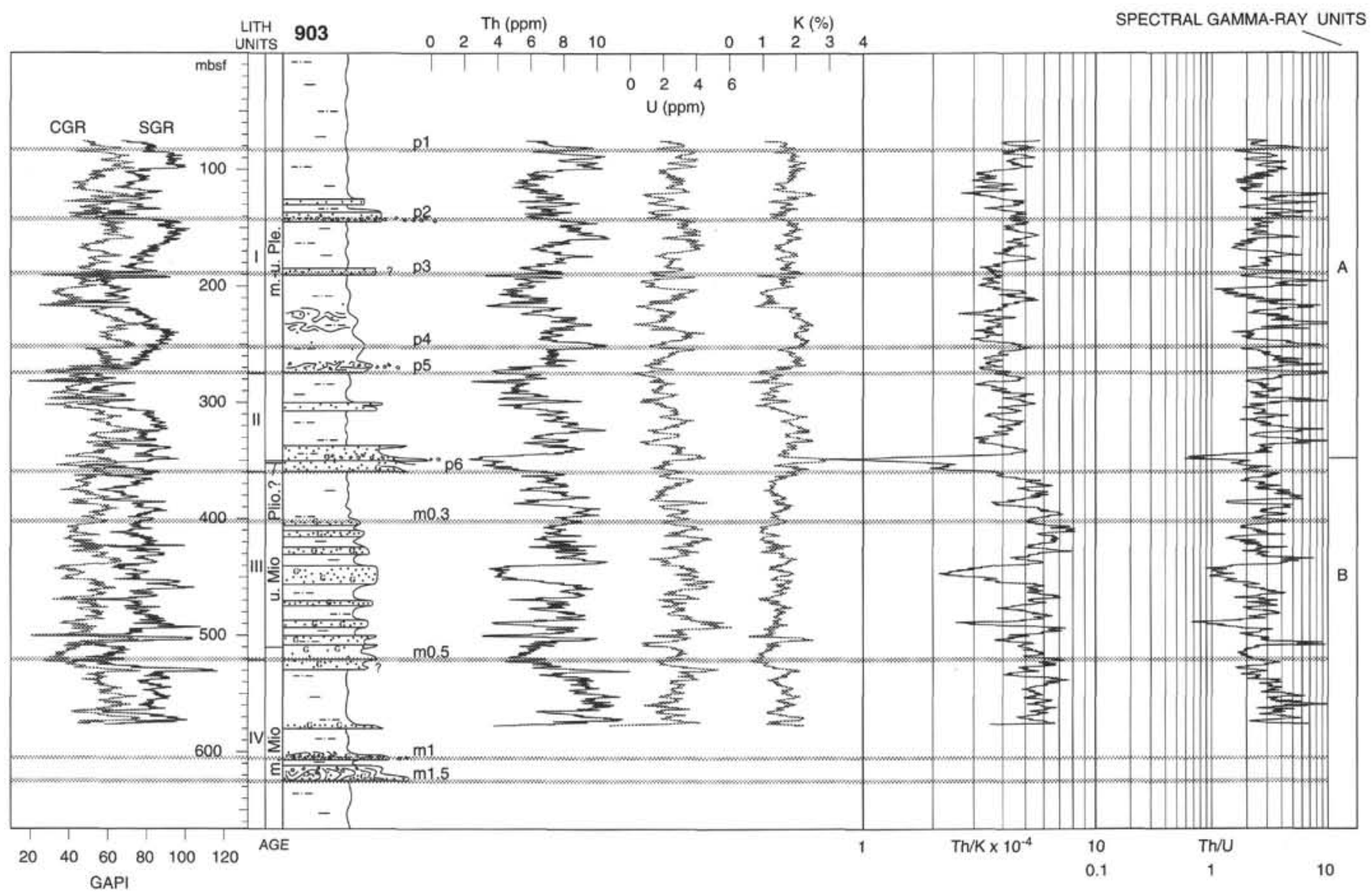

Figure 3. Spectral gamma-ray logs for Hole 903A (key as for Fig. 2).

present-day outer continental shelf or slope (Fig. 1), and sediment was either not reaching the area, or was being by-passed into deeper water. The sediments giving rise to Unit A represent the resumption of progradation in the Pleistocene, albeit showing a steeper, hummocky, blanket-like character that contrasts with the gentle sigmoidal forms of the Miocene. This probably reflects deposition principally by mass transport in the Pleistocene rather than hemipelagic settling which dominated earlier.

\section{Th/K, CLAY MINERALOGY, PALEOGEOGRAPHY, AND PALEOCLIMATE}

It has been suggested that $\mathrm{Th} / \mathrm{K}$ ratios may be used to indicate clay mineral assemblages on the basis of empirical relationships (Hassan and Hossin, 1975; Edmundson and Raymer, 1979; Quirein et al., 1982; Fertl, 1983; Herron, 1986). The reliability of this method has been questioned by Hurst (1990), who used additional data from
Clark et al. (1966), Deer et al. (1966), and Ellis et al. (1988) to show that the Th/K compositional fields of common clay minerals exhibited much greater overlap than had been appreciated previously. For example, the $\mathrm{Th} / \mathrm{K}$ ratio of kaolinite ranges from 10 to $\infty$ rather than $10-28$ as suggested by Quirein et al. (1982). Indeed, experimental evidence indicates that kaolinite has a very low Th-adsorption capacity (Hurst, 1990) and authigenic kaolinite is thus unlikely to acquire high $\mathrm{Th} / \mathrm{K}$ ratios by adsorption from Th-poor marine or formation waters (cf. Humphreys and Lott, 1990). Nonetheless, the usually paleopedologic conditions of kaolinite formation cause relative concentration of Th at the expense of K (Adams and Richardson, 1960; Myers, 1989), and clay minerals formed by soil processes and transported as detrital grains are likely to show considerable compositional contrasts compared with the same phases formed in situ in marine sediments by authigenic or diagenetic processes. Rider (1991) has stated that the relationship between clay mineralogy and spectral gammaray logs needs both empirical and theoretical justification; the following section addresses some empirical aspects. 


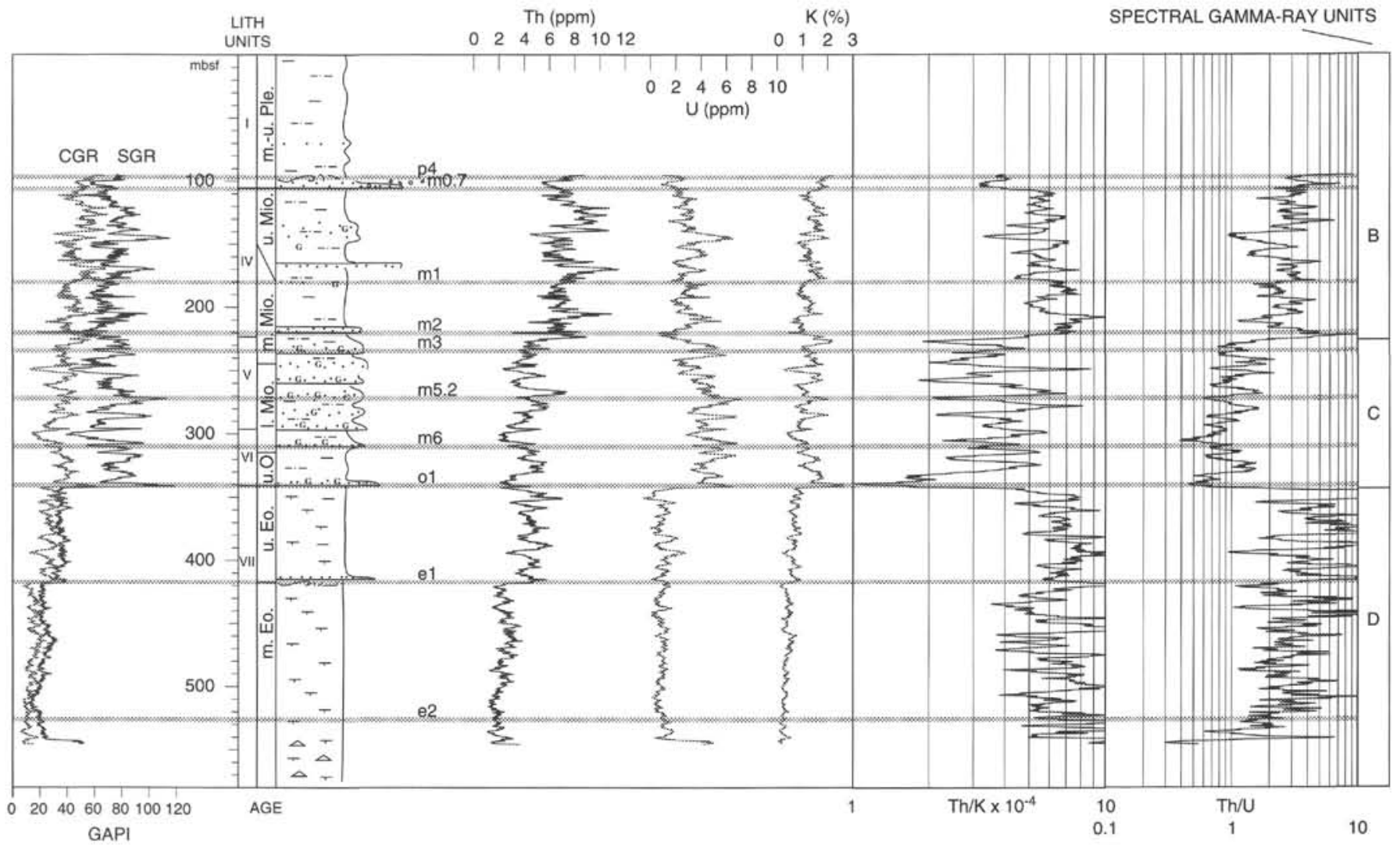

Figure 4. Spectral gamma-ray logs for Hole 904A (key as for Fig. 2).

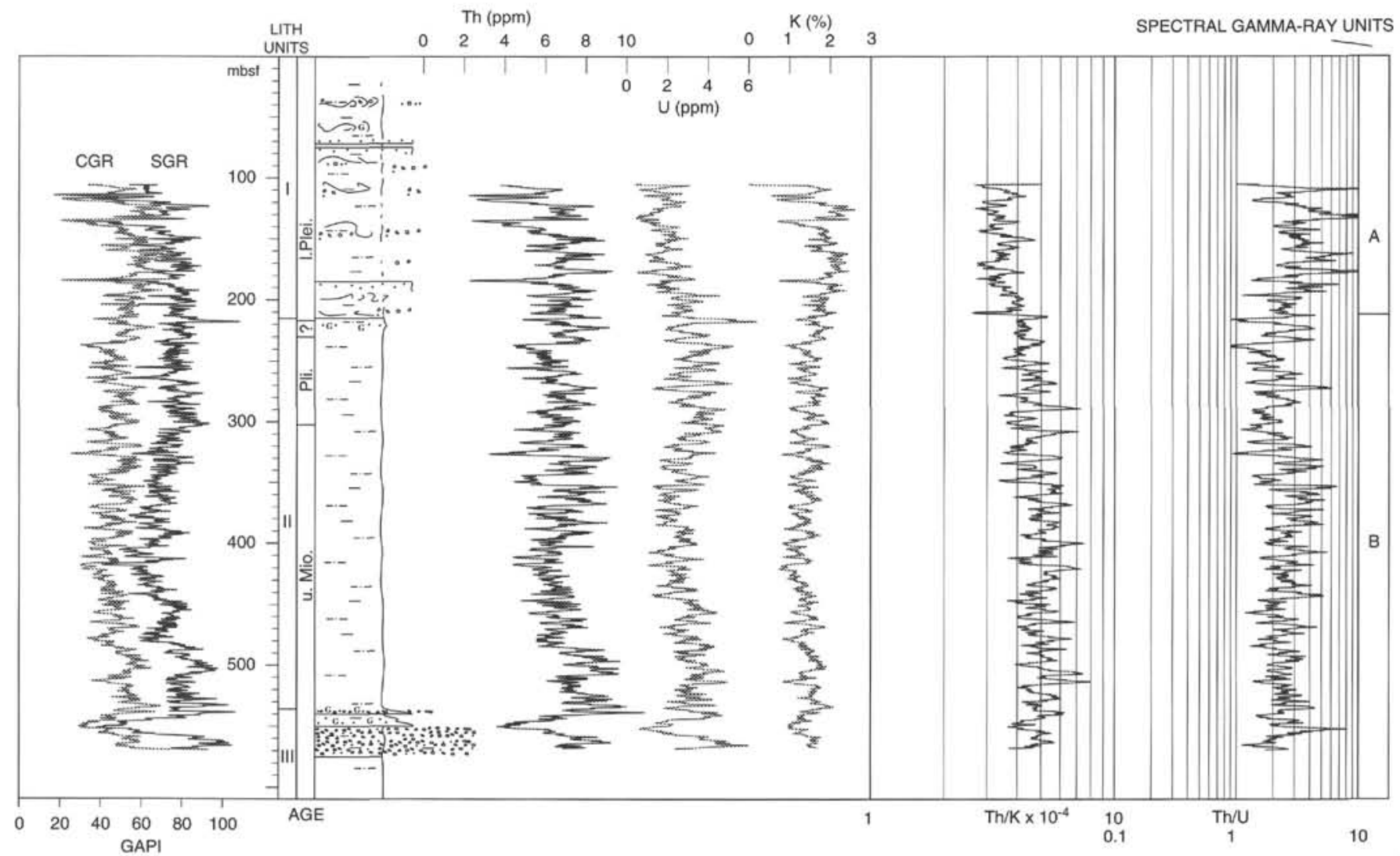

Figure 5. Spectral gamma-ray logs for Hole 905A (key as for Fig. 2). 


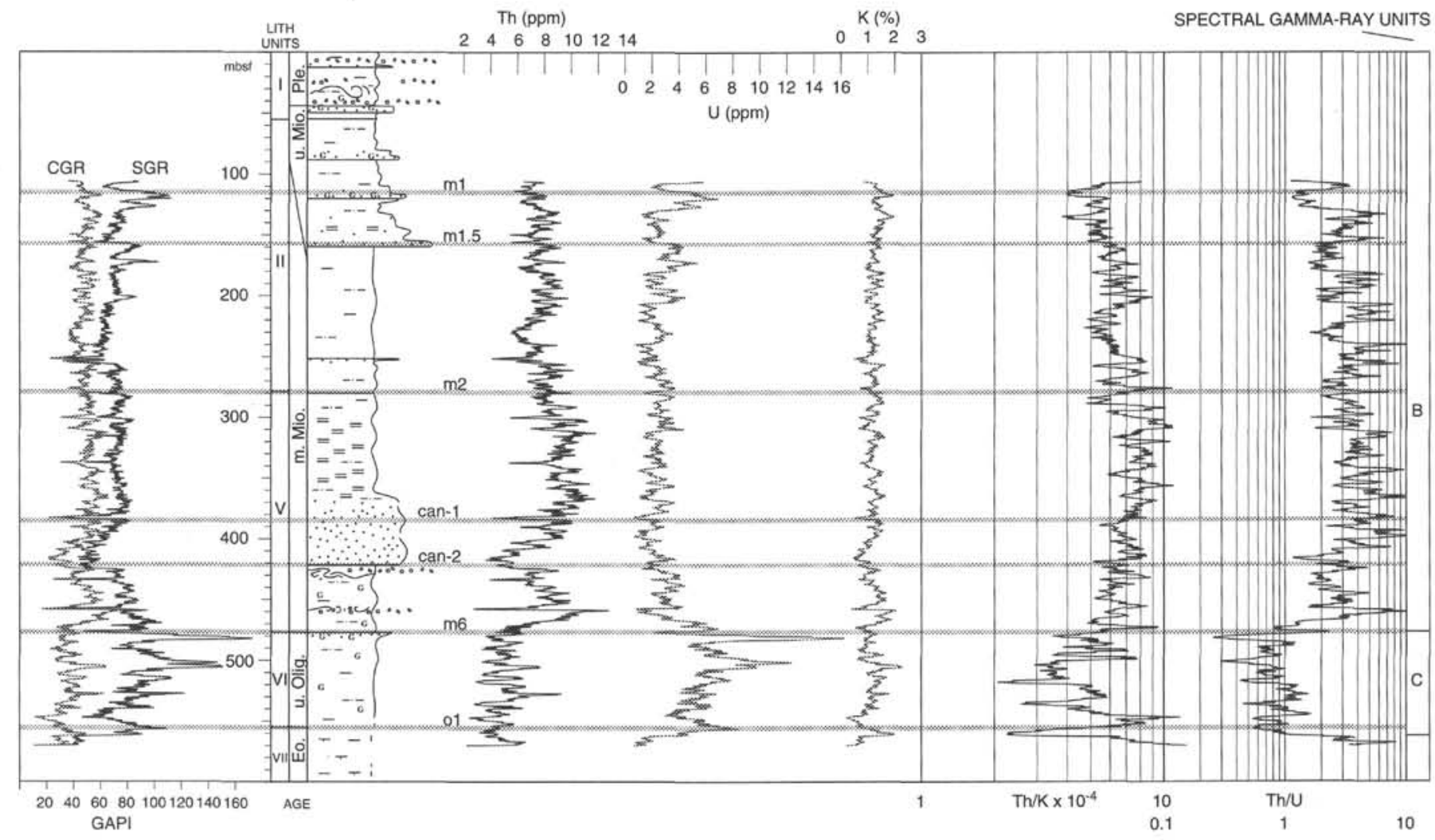

Figure 6. Spectral gamma-ray logs for Hole 906A (key as for Fig. 2).

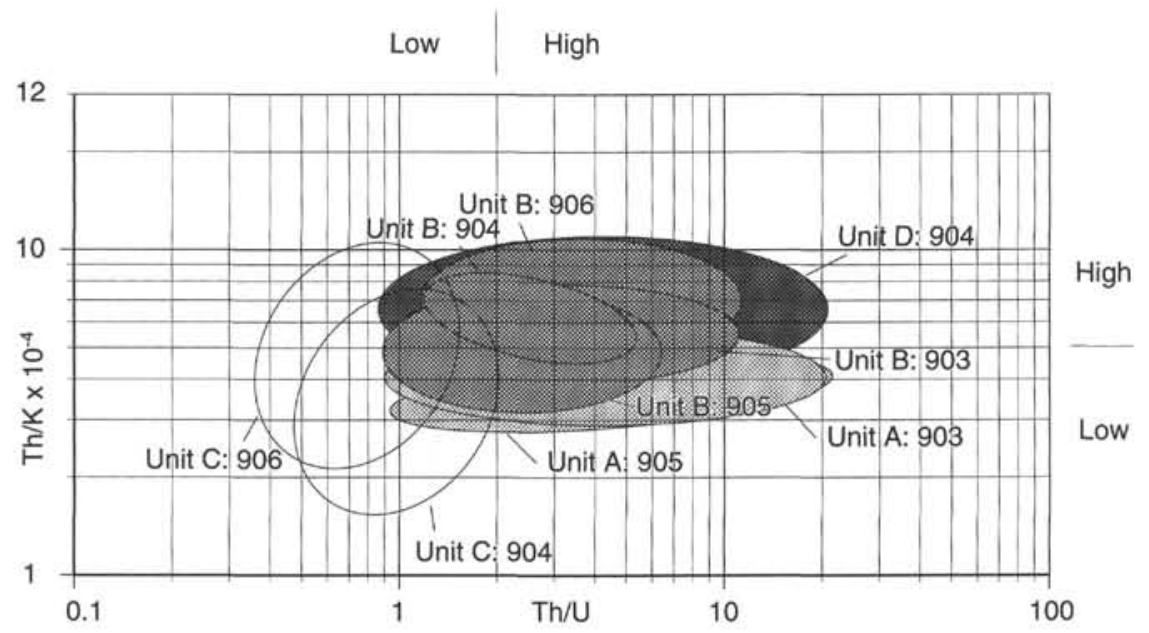

Figure 7. Summary of plots of $\mathrm{Th} / \mathrm{K}$ ratios against $\mathrm{Th} / \mathrm{U}$ ratios for the spectral gamma-ray units discussed in the text. Outlying data points resulting from glauconitic beds at unit boundaries are excluded from the compositional fields (compare Figs. 3-6)

For the Cenozoic of the New Jersey Margin, clay-mineral assemblages are overwhelmingly detrital in origin (Deconinck and Vanderaveroet, this volume). These authors determined clay-mineral assemblages for the clay-sized fraction by X-ray diffraction (XRD) for most of the succession, but exclusively from Sites 903 and 905 . Clay-mineral data do not always coincide with high quality spectral gammaray logs at these two sites. Happily, clay-mineral and spectral gamma-ray data do overlap at Site 903 for the middle Miocene to Pleistocene interval through which clay assemblages are dominated by kaolinite or illite (Fig. 8A). There are only relatively minor changes in the content of subordinate mixed-layer illite/smectite, which constitutes around $20 \%$ of the total clay assemblage. The illite/kaolinite ratio was determined on XRD diagrams by the relative intensity of the 001 peaks of kaolinite and illite (Deconinck and Vanderaveroet, this volume). Illite/kaolinite ratios are clearly correlated with $\mathrm{Th} / \mathrm{K}$ ratios throughout this interval (Fig. 8A). Assuming that no other phases are involved, the relationship implies that the illite has a $\mathrm{Th} / \mathrm{K}$ ratio of about 3, close to the average value suggested by Quirein et al. (1982). (The $\mathrm{Th} / \mathrm{K}$ ratio of the kaolinite is impossible to determine precisely because the change in $\mathrm{Th} / \mathrm{K}$ ratio with increasing kaolinite/illite ratio 

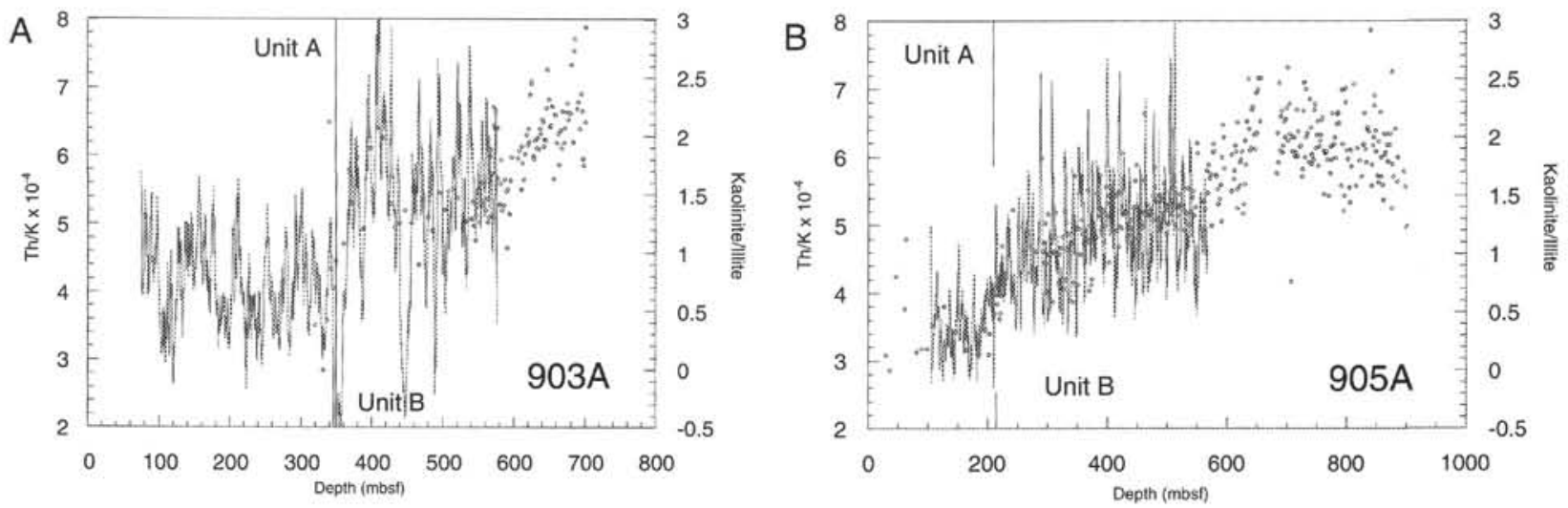

Figure 8. Plots of kaolinite/illite ratios (Deconinck and Vanderaveroet, this volume) and log-derived Th/K ratios for (A) Hole 903A and (B) Hole 905A. Open circles $=$ clay mineral ratios; continuous lines $=\mathrm{Th} / \mathrm{K}$ ratios. In the case of Hole $903 \mathrm{~A}$ the clay mineralogy is dominated by kaolinite and illite except around 360,445 , and $490 \mathrm{mbsf}$, where glaucony grains are very abundant (Shipboard Scientific Party, 1994b). In Hole 905A mixed-layer illite/smectite dominates the clay-mineral assemblages below $220 \mathrm{mbsf}$, and exact correlation between $\mathrm{Th} / \mathrm{K}$ ratio and kaolinite/illite ratio is coincidental.

depends not only on the $\mathrm{Th} / \mathrm{K}$ ratio of the kaolinite, but also on the absolute content of these elements in both clay-mineral phases, which are also unknown quantities.)

Significant departure from correlation between kaolinite/illite and $\mathrm{Th} / \mathrm{K}$ ratios occurs only where $\mathrm{Th} / \mathrm{K}$ ratios show anomalously low values (340-360, 440-450, and 480-495 mbsf at Site 903). Glauconitic mineral content is as high as $60 \%-80 \%$ over these intervals (Shipboard Scientific Party, 1994b). Glauconitic minerals have very low Th/K ratios (Hassan and Hossin, 1975; Hassan et al., 1976). Low $\mathrm{Th} / \mathrm{K}$ ratios would be easily explained by the mechanisms for glauconitization proposed by Odin and Matter (1981) and Odin and Fullagar (1988) because these involve crystal growth by incorporation of ions from marine and pore waters, with the initial substrate playing no direct role in the composition of the glauconitic product. In contrast, Clauer et al. (1992) and Stille and Clauer (1994) have proposed dissolution-reprecipitation of an initial clay-rich substrate in the early stages of glauconitization, in a system that is effectively shielded from the marine environment. It is not at all obvious how such a process could lead to significantly lower $\mathrm{Th} / \mathrm{K}$ ratios in less mature glauconitic intervals (note, though, that in the case of Leg 150, most of the glauconitic minerals encountered are very mature; S.R. McCracken, pers. comm., 1995).

The relationship between $\mathrm{Th} / \mathrm{K}$ and illite/kaolinite ratios at Site 905 is more complex than it is at Site 903 because illite/smectite mixed-layer clays, comprising $50 \%-60 \%$ of the clay-mineral assemblages, are dominant over either illite or kaolinite through the upper Miocene and Pliocene of lithologic Unit II. Furthermore, the Pleistocene of lithologic Unit I comprises, in addition to these, chlorite and mixed-layer illite/vermiculite (Deconinck and Vanderaveroet, this volume, fig. 7). Thus, it is somewhat remarkable that $\mathrm{Th} / \mathrm{K}$ ratios also show a close correlation with kaolinite/illite ratios at Site 905 (Fig. 8B). The reason for this probably lies in the low total Th and $\mathrm{K}$ contained within chlorite (Quirein et al., 1982) and low relative proportion of illite/vermiculite to other clays $(<15 \%)$. Also, illite/smectite is known to have $\mathrm{Th} / \mathrm{K}$ ratios and total Th and $\mathrm{K}$ intermediate between kaolinite and illite (Hassan and Hossin, 1975) and hence have no significant effect on the $\mathrm{Th} / \mathrm{K}$ ratios when illite/kaolinite ratios are around unity, as they are in lithologic Unit II. In lithologic Unit I, where they might otherwise have been expected to have a marked effect on the $\mathrm{Th} / \mathrm{K}$ ratios because of the low kaolinite/illite ratio, mixedlayer illite/smectite comprises only about $15 \%$ of the clay mineral assemblages. It is likely that $\mathrm{K}$-feldspar also contributes significantly to the low $\mathrm{Th} / \mathrm{K}$ ratios in the sandy intervals of Unit A, judging by shipboard XRD data (see appropriate site chapters in Mountain, Miller, Blum, et al., 1994).
Demonstration of a close relationship between changes in clay mineralogy and $\mathrm{Th} / \mathrm{K}$ ratios through a limited part of the succession does not prove that a close relationship exists through the whole section. However, the broad trends in $\mathrm{Th} / \mathrm{K}$ ratios summarized in Figure 7 can certainly be sensibly explained in terms of changing clay mineralogy.

The Eocene section is dominated by smectitic clays and at Site 903 it comprises Clay Mineral Zone (CMZ) IV of Deconinck and Vanderaveroet (this volume). These dominantly pelagic sediments correspond precisely to spectral gamma-ray Unit D at Site 904, which has a uniformly high $\mathrm{Th} / \mathrm{K}$ ratio of about $7 \pm 3$ (Fig. 7). Deconinck and Vanderaveroet (this volume) believe that the smectitic clays were derived from humid tropical soils (Chamley, 1989; Poag and Sevon, 1989) on the North American continent and delivered to the site of deposition by winds, a mechanism also suggested for the clays in some Cretaceous chalks (Lever and McCave, 1983; Kimblin, 1992). The high $\mathrm{Th} / \mathrm{K}$ ratios of Unit D support the inference of a detrital origin for the clays through a derivation from humid tropical soils.

The Oligocene to middle Miocene section of Site 903 contains illite, kaolinite, and mixed-layer illite/smectite. Throughout the interval, the proportions of illite and kaolinite increase upward at the expense of illite/smectite (CMZ III of Deconinck and Vanderaveroet, this volume). The interval corresponds closely to Unit C of Site 904 and Site 906, but inferences regarding the precise relationship of $\mathrm{Th} / \mathrm{K}$ ratios to clay mineralogy are obscured not only by the threecomponent nature of the detrital clay assemblages, but also by the very common occurrence of glauconitic minerals. However, it is apparent that there is a considerable range of $\mathrm{Th} / \mathrm{K}$ ratios, from an upper extreme of about 10 at Site 906 , compatible with the high concentrations of kaolinite and illite/smectite, to a lower limit of about 2 at Site 904 , compatible with the locally high glauconitic content (Fig. 7). (Ratios of $\mathrm{Th} / \mathrm{U}$ are consistently low through Unit C, probably because U content is moderate to high in all facies, even at Site 904, the least uraniferous of the slope sites.)

The rise in proportion of illite in the clay mineral assemblages from the Eocene to the Miocene can be explained simply by a change from predominantly chemical weathering in the Eocene to predominantly mechanical weathering in the Miocene (Poag and Sevon, 1989), as climatic conditions in the source regions showed a progressive deterioration (Wolfe, 1978, 1992; Barron, 1989). In this context, the increase in kaolinite is somewhat surprising and is attributed by Deconinck and Vanderaveroet (this volume) to an increase in global humidity in the middle Miocene supplemented strongly by denudation of crystalline basement or a sedimentary Eocene-Cretaceous source in the Appalachians. An additional factor may be the increas- 
ingly proximal prodeltaic depositional environment for the clays through the Oligocene to middle Miocene (cf. Porrenga, 1966; Gibbs, 1977), an effect perhaps subsequently counteracted by continued climatic deterioration.

The middle Miocene to Pliocene section, dominated by illite and kaolinite at Site 903 and mixed-layer illite/smectite at Site 905 comprises CMZ II of Deconinck and Vanderaveroet (this volume) and closely approximates to Unit B. High to moderate kaolinite/illite ratios are reflected in high overall $\mathrm{Th} / \mathrm{K}$ ratios. The lowest ratios are found at Site 905 , where they are moderated by the high mixed-layer illite/smectite content as discussed above. The highest ratios are shown at Site 906 , where the section is dominated by canyon-fill sediment equivalent in age to strata with the highest kaolinite/illite ratios at Site 903 (Figs. 3, 6,7). Site 904 shows intermediate characteristics. Thus, once again variation in $\mathrm{Th} / \mathrm{K}$ ratios can adequately be explained in terms of changing clay mineral assemblages at sites for which no clay-mineral data are available.

Finally, the Leg 150 data set allows an assessment of the extent to which $\mathrm{Th} / \mathrm{K}$ ratios indicate proximal vs. distal sedimentary environments in mudrocks by virtue of their relationships to kaolinitic (proximal) to illitic (distal) clay mineral assemblages produced through a mechanism of differential settling (Myers, 1987; Myers and Wignall, 1987; Parkinson, 1994, 1996). From the preceding discussion, it can be concluded that although the $\mathrm{Th} / \mathrm{K}$ ratios might have been largely controlled by increasing proximality over the Oligocene to Miocene interval considered in this study (Greenlee et al., 1992), the trends in ratios are very strongly modified by climatic change (in this case, cooling and variable humidity affecting the weathering processes), changes in depth of erosion of source terrains, development of glaucony, and changes in the depositional mechanisms for clay particles, such as the switch from predominantly aeolian to predominantly marine transport as may have occurred across the Eocene/Oligocene boundary. This is not to say that spectral gamma-ray data cannot be used to elucidate large-scale trends in paleoclimate or relative proximality of sedimentary environment as suggested by Parkinson (1994, 1996) but only to emphasize that considerable additional data may be required to isolate any one factor as dominant.

\section{GAMMA-RAY PEAKS AS MAXIMUM FLOODING SURFACES}

Gamma-ray peaks are commonly interpreted as maximum flooding surfaces where they occur in offshore settings (e.g., Milton et al., 1990; Partington et al., 1993a, 1993b) on the basis that they represent relatively argillaceous intervals within sandstones, organic-rich intervals within argillaceous successions, or mineralized surfaces within a condensed section (see reviews of Vail et al., 1991, and Armentrout et al., 1993, for fuller bibliography). Although this may generally be correct, there are numerous counter examples in which gamma-ray peaks do not represent maximum flooding surfaces, mostly from littoral facies or related to meteoric diagenetic phenomena. For example, a gamma spike may result from placer deposition of Th-bearing minerals in a beach environment or from authigenic U-bearing minerals deposited in limestones as a result of subaerial exposure (Rider, 1991; Doveton, 1994, and references therein).

The character of the gamma-ray logs through the glauconitic deposits considered in the present study illustrates well the caution that has to be exercised in interpreting total gamma-ray peaks as maximum flooding surfaces, even for offshore depositional settings. Glauconitic intervals are an important component of the sequence stratigraphic architecture of the New Jersey Margin, although their precise sequence stratigraphic significance is variable (McCracken et al., this volume). An additional complicating factor is that a range of spectral gamma-ray characteristics is recognized within otherwise similar glauconitic facies.
Take, as an example, Unit B of Hole 903A, in which glauconitic beds show consistently reduced Th content as compared to the background sediment (lithologic Units II and III; Fig. 3). Depletion of Th has a marked effect on the $\mathrm{Th} / \mathrm{K}$ and $\mathrm{Th} / \mathrm{U}$ ratios, but its effect on the SGR $\log$ is compensated for by increased $\mathrm{U}$ and/or $\mathrm{K}$ content. Hence, there is little vertical change in total gamma-ray emission associated with these levels, despite their evident large-scale sequence stratigraphic significance, particularly the very thin interval containing Pliocene fossils around 350 mbsf at Site 903 (Figs. 1, 2).

Even more striking are the changes downslope in Unit $\mathrm{C}$ from Site 902 to Site 904 (Fig. 9). At Site 902, prominent gamma-ray maxima correspond to nonglauconitic mudstone intervals with raised TOC, lying between glauconitic sandstones (e.g., 520 mbsf, Figs. 2, 9A); the spectral gamma-ray log shows that these maxima are produced by an abundance of $\mathrm{U}$. In contrast, the large peaks are not present at Site 904 where TOC content is lower: instead, the glauconitic sands form moderate gamma-ray peaks produced by elevated $\mathrm{K}$, Th, and $\mathrm{U}$ content (Figs. 2, 9B). At the base of Unit C at Site 904 (340 mbsf; Fig. 4), a glauconitic sand also produces a marked gamma-ray peak; in this case the Th content is low, but the concomitant increase in both $\mathrm{U}$ and $\mathrm{K}$ more than compensates for the lack of Th. The differences between Site 904 and Site 902 cannot be attributed to hole conditions at Site 902, which were poor only above 500 mbsf (Shipboard Scientific Party, 1994a).

If it is assumed that organic-rich mudstones at Site 902 do not pass laterally into glauconitic sands at Site 904, then it follows that the total gamma-ray maxima cannot be correlated between these two timeequivalent intervals, despite their close geographic proximity and superficially similar facies. Indeed, in passing from the upslope to downslope setting, the gamma-ray maxima shift between surfaces with potentially contrasting sequence stratigraphic significance (Fig. 9C).

Variable spectral gamma-ray responses from glauconitic intervals are unsurprising given the wide range of compositions exhibited by glauconitic minerals. Immature glauconitic smectite, with $\mathrm{K}$ content of $<4 \%$, which have been at the seafloor between $10^{3}$ and $10^{4} \mathrm{yr}$, have chemical and isotopic compositions strongly influenced by any original detrital component. In contrast, more mature glauconitic micas, with $\mathrm{K}$ content up to $9 \%$, may take $10^{6} \mathrm{yr}$ to develop on the seafloor and have chemical and isotopic compositions strongly influenced by the contemporaneous sea water (Odin and Fullagar, 1988; Stille and Clauer, 1994). Stille and Clauer (1994) also stress the importance of a phosphatic component in influencing the isotopic composition of the mature glauconitic micas they studied. Since any phosphate component is likely to contain $\mathrm{U}$, a relative increase in both $\mathrm{K}$ and $\mathrm{U}$ in the more mature glauconitic minerals is to be expected. Consequently, a mature glaucony facies with low content of other clays, such as is likely to result from a major transgression, will produce a gammaray peak dominated by $\mathrm{K}$ and possibly $\mathrm{U}$. However, in even slightly expanded successions not only are the glauconitic minerals likely to be less mature, but their contribution to the total gamma-ray signal may be masked by increased contributions from other sources such as nonglauconitized detrital clays. Importantly for the example given above, $U$ fixation was an effective process in the more expanded upslope site, and this occurred preferentially in the nonglauconitic intervals.

\section{SUMMARY AND CONCLUSIONS}

Spectral gamma-ray logs of the Cenozoic sediments below the present-day Atlantic continental slope and upper rise, offshore New Jersey, can be subdivided into four spectral gamma-ray units characterized by distinct patterns of: total gamma radiation; Th, $\mathrm{U}$, and $\mathrm{K}$ content; and $\mathrm{Th} / \mathrm{K}$ and $\mathrm{Th} / \mathrm{U}$ ratios. These units (A-D) are of genetic significance in that they correspond to the major elements of the 
A

902

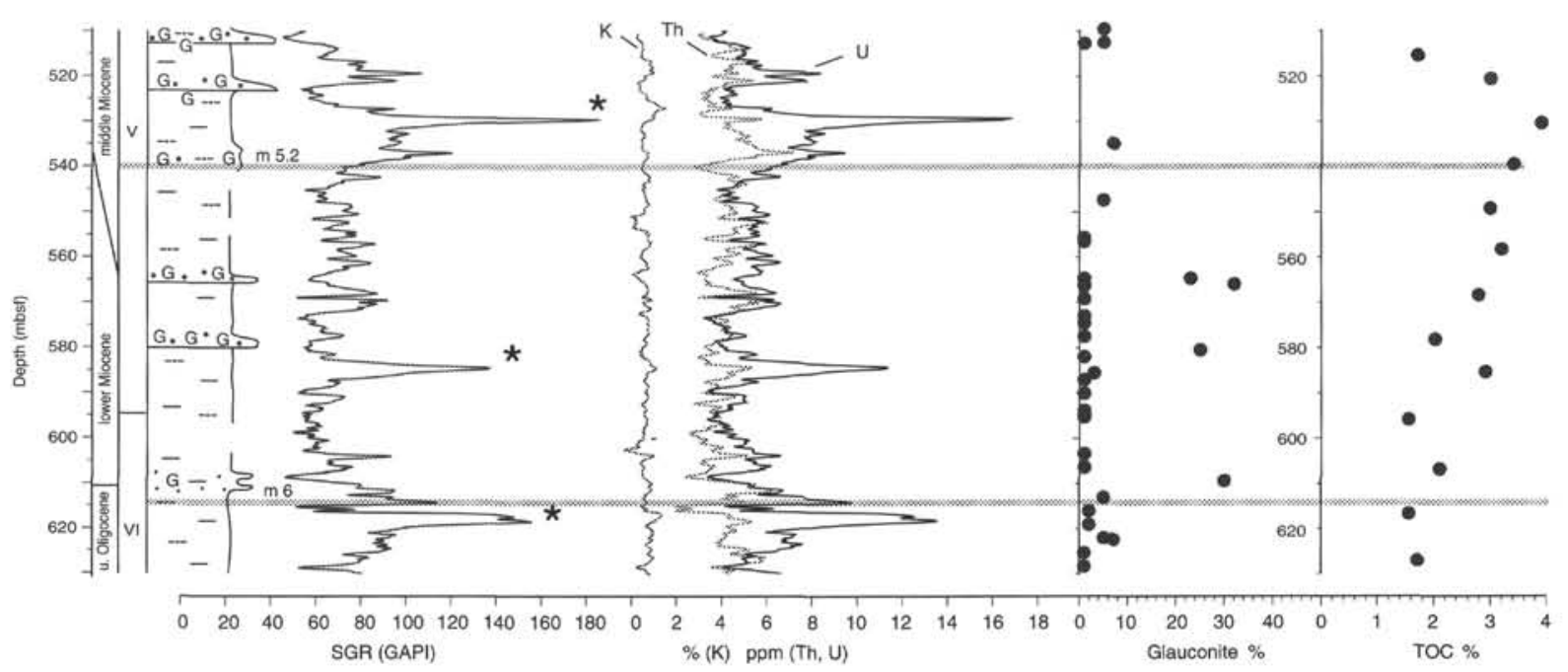

B

904

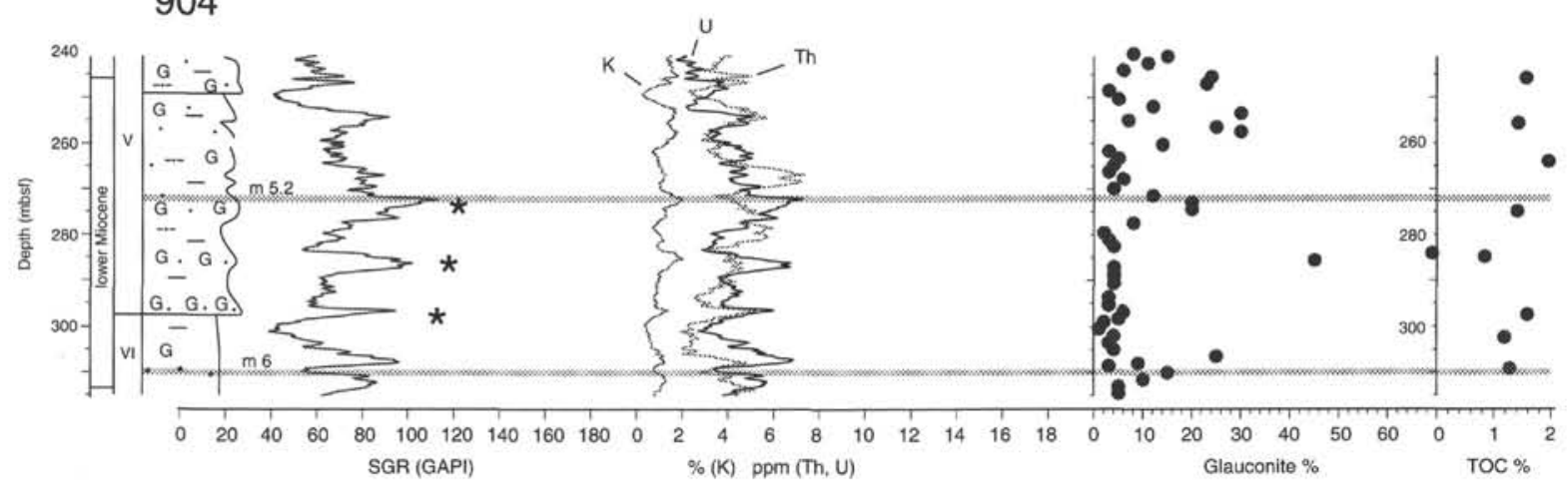

C

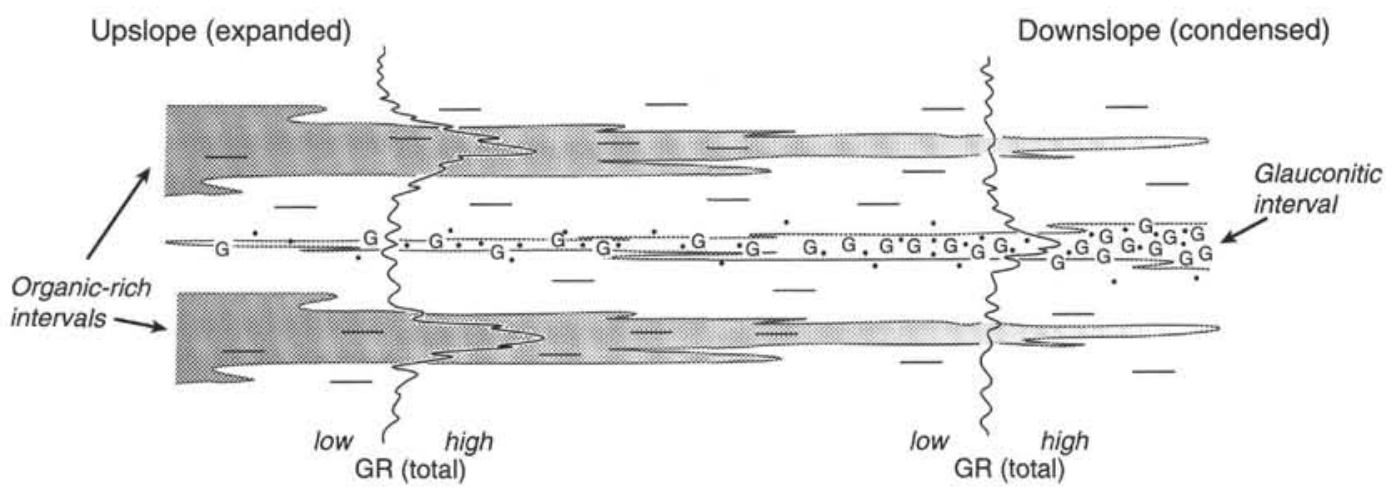

Figure 9. A. Spectral gamma-ray data from the upslope Site 902 showing correspondence of prominent gamma-ray peaks (marked *) to nannofossil-rich and diatomaceous mudstones. The peaks are produced by high $\mathrm{U}$ content and correlate broadly with high TOC values. B. Spectral gamma-ray data from the thinner downslope Site 904 showing correspondence of moderate gamma-ray peaks (marked *) to glauconitic sandy intervals. (Lithostratigraphy, chronostratigraphy, simplified lithologic columns, "glauconite" smear-slide estimates, and TOC analyses are as given in Mountain, Miller, Blum, et al., 1994; reflector positions are from G.S. Mountain, pers. comm.; see Fig. 2 for key to symbols.) C. Cartoon illustrating interpreted shift of the gamma-ray peaks from the organic-rich intervals to the glauconitic intervals passing downdip. Clearly, the gamma-ray maxima cannot be correlated between the sites and do not have the same sequence stratigraphic significance. Note that both glauconitic and organic-rich intervals may be interpreted as maximum flooding surfaces in a relatively sedimentstarved distal setting (cf. McCracken et al., this volume; Tyson, 1996). 
large-scale, "second-order" sequence stratigraphic architecture of the Atlantic continental margin. Stratigraphic variation in $\mathrm{Th} / \mathrm{K}$ ratios within and between these units can be adequately accounted for by changes in detrital clay-mineral assemblages. Thus, high $\mathrm{Th} / \mathrm{K}$ ratios are associated with clay-mineral suites dominated by kaolinite and/or smectite, whereas low $\mathrm{Th} / \mathrm{K}$ ratios are associated with clay-mineral assemblages dominated by illite. Localized concentrations of glauconitic minerals result in much lower $\mathrm{Th} / \mathrm{K}$ ratios than predicted by the background clay-mineral assemblages. The glauconitic minerals appear not to incorporate or adsorb Th when they form authigenically near the seafloor.

Large-scale trends in $\mathrm{Th} / \mathrm{K}$ ratios through the Cenozoic of the New Jersey Margin, being closely related to detrital clay mineral assemblages, reflect processes occurring both in the hinterland and during transport. Thus, the change from high $\mathrm{Th} / \mathrm{K}$ to low $\mathrm{Th} / \mathrm{K}$ ratios across the Eocene/Oligocene boundary (between Units D and C) can be explained partly by a change from aeolian to marine transport for the clays, and partly by a change in climate and/or sediment source area. The low $\mathrm{Th} / \mathrm{K}$ ratio of Unit $\mathrm{C}$ must also result partly from increased $\mathrm{K}$ content through glauconitization. Conversely, the change from high $\mathrm{Th} / \mathrm{K}$ ratios in the upper Miocene and Pliocene to low $\mathrm{Th} / \mathrm{K}$ ratios in the Pleistocene (between Units B and A) has a very different origin: initiation of deposition of glacially derived clay minerals dominated by illite, with possibly a contribution from K-feldspar in the silt and sand fraction. Only in the case of the upper Oligocene to middle Miocene (Unit C and B transition) can a reasonable case be made for decreased distance to shoreline as a cause of higher $\mathrm{Th} / \mathrm{K}$ ratios by a mechanism of differential settling. Even in this instance, however, the change in clay mineralogy may alternatively be ascribed to rejuvenation of kaolinite-rich Eocene-Cretaceous Appalachian source terrains and increased middle Miocene humidity.

Glauconitic intervals show a varied spectral gamma-ray signal as befits their variable chemistry. Only those intervals associated with distal hiatuses of long duration produce consistent total gamma-ray peaks; others are neutral, and some are expressed as relative troughs. Distal facies containing significant quantities of glauconitic minerals may produce gamma-ray $\log$ responses that are difficult to interpret without spectral data.

\section{ACKNOWLEDGMENTS}

I thank Julian Bessa, John Compton, Jean-Francois Deconinck, Bobby Hesselbo, Jenny Huggett, Robert Knox, Juan Lorenzo and Neil Parkinson for useful discussion of this topic. Particular thanks go to Jean-Francois Deconinck and Patrice Vanderaveroet for allowing me to incorporate their clay-mineral data in this paper. I am grateful also to the referees, Hervé Chamley and Richard Jarrard, for their thorough scrutiny of the initial manuscript; their comments have helped to improve the final version significantly.

\section{REFERENCES}

Adams, J.A.S., and Richardson, K.A., 1960. Thorium, uranium and zirconium concentrations in bauxite. Econ. Geol., 55:1653-1675.

Adams, J.A.S., and Weaver, C.E., 1958. Thorium-to-uranium ratios as indicators of sedimentary processes: example of concept of geochemical facies. AAPG Bull., 42:387-430.

Armentrout, J.M., Malecek, S.J., Fearn, L.B, Sheppard, C.E., Naylor, P.H., Miles, A.W., Desmarais, R.J., and Dunay, R.E., 1993. Log-motif analysis of Paleogene depositional systems tracts, Central and Northern North Sea: defined by sequence stratigraphic analysis. In Parker, J.R. (Ed.), Petroleum Geology of Northwest Europe: Proceedings of the 4th Conference. Geol. Soc. Spec. Publ. London, 45-57.

Barron, E.J., 1989. Climate variations and the Appalachians from the Late Paleozoic to the present: results from model simulations. Geomorphology, 2:99-118.

Bjørlykke, K., Dypvik, H., and Finstad, K.G., 1975. The Kimmeridge shale: its composition and radioactivity. NFP Jurassic Northern N. Sea Symp. Stavanger, Pap. 12:1-20.
Borehole Research Group, 1990. Wireline Logging Manual: Palisades, NY (Lamont-Doherty Geological Observatory, Columbia Univ.).

Chamley, H., 1989. Clay Sedimentology: Berlin (Springer-Verlag).

Clark, S.P., Peterman, Z.E., and Heier, K.S., 1966. Abundances of uranium, thorium and potassium. Handbook of Physical Constants, Section 24. Mem.-Geol. Soc. Am., 97:521-541.

Clauer, N., Stille, P., Keppens, E., and O'Neil, J.R., 1992. Sr isotope constraints on the process of glauconitization. Geology, 20:133-136.

Deer, W.A., Howie, R.A., and Zussman, J., 1966. An Introduction to the Rock-Forming Minerals: London (Longman Group).

Doveton, J.H., 1994. Geologic log interpretation. Soc. Econ. Paleontol. Mineral., Short Course No. 29.

Edmundson, H.N., and Raymer, L.L., 1979. Radioactive logging parameters for common minerals. Trans. SPWLA 22nd Ann. Log. Symp., Pap. O.

Ellis, D., Howard, J., Flaum, C., McKeon, D., Scott, H., Serra, O., and Simmons, G., 1988. Mineral logging parameters: nuclear and acoustic. Tech. Rev., 36:38-52.

Fertl, W.H., 1983. Gamma-ray spectral logging: a new evaluation frontier, Part I-principles. World Oil, 196:79-82.

Gibbs, R.J., 1977. Clay mineral segregation in the marine environment. $J$. Sediment. Petrol., 47:237-243.

Glendron, C.R., Cahill, R.A., and Gilkeson, R.H., 1988. Comparison of spectral gamma-ray (SGR) well logging data with instrumental neutron activation analysis (INAA) data for rock types in northern Illinois. Log Analyst, 29:345-357.

Greenlee, S.M., Devlin, W.J., Miller, K.G., Mountain, G.S., and Flemings, P.B., 1992. Integrated sequence stratigraphy of Neogene deposits, New Jersey continental shelf and slope: comparison with the Exxon model. Geol. Soc. Am. Bull., 104:1403-1411.

Hassan, M., and Hossin, A., 1975. Contribution a l'étude des comportements du thorium et du potassium dans les roches sédimentaires. $C$. $R$. Acad. Sci. Ser. 2, 280:533-535.

Hassan, M., Hossin, A., and Combaz, A., 1976. Fundamentals of the differential gamma-ray log-interpretation techniques. Trans. SPWLA 17th Annu. Logging Symp., $\mathrm{H1}-\mathrm{H} 18$.

Herron, M.M., 1986. Mineralogy from geochemical well logging. Clays Clay Miner., 34:204-213.

Hoppie, B.W., Blum, P., and the Shipboard Scientific Party, 1994. Natural gamma-ray measurements on ODP cores: introduction to procedures with examples from Leg 150. In Mountain, G.S., Miller, K.G., Blum, P., et al., Proc. ODP, Init. Repts., 150: College Station, TX (Ocean Drilling Program), 51-59.

Humphreys, B., and Lott, G.K., 1990. An investigation into nuclear log responses of North Sea Jurassic sandstones using mineralogical analysis. In Hurst, A., Lovell, M.A., and Morton, A.C. (Eds.), Geological Applications of Wireline Logs. Geol. Soc. Spec. Publ. London, 48:223-240.

Hurst, A., 1990. Natural gamma-ray spectrometry in hydrocarbon-bearing sandstones from the Norwegian Continental Shelf. In Hurst, A., Lovell, M.A., and Morton, A.C. (Eds.), Geological Applications of Wireline Logs. Geol. Soc. Spec. Publ. London, 48:211-222.

Kimblin, R.T., 1992. The origin of clay minerals in the Coniacian Chalk of London. Clays Clay Miner., 27:389-392.

Kochenov, A.V., Korolev, K.G., Dubinchuk, V.T., and Medvedev, Y.L., 1977. Experimental data on the conditions of precipitation of uranium from aqueous solutions. Geochem. Int., 1977:82-87.

Koczy, F.F., 1956. Geochemistry of the radioactive elements in the ocean. Deep-Sea Res. Part A, 3:93-103.

Langmuir, D., and Herman, J.S., 1980. The mobility of thorium in natural waters at low temperatures. Geochim. Cosmochim. Acta, 44:1753-1766.

Lever, A., and McCave, I.N., 1983. Eolian components in Cretaceous and Tertiary North Atlantic sediments. J. Sediment. Petrol., 53:811-832.

Milton, N.J., Bertram, G.T., and Vann, I.R., 1990. Early Palaeogene tectonics and sedimentation in the Central North Sea. In Hardman, R.F.P., and Brooks, J. (Eds.), Tectonic Events Responsible for Britain's Oil and Gas Reserves. Geol. Soc. Spec. Publ. London, 55:339-351.

Mountain, G.S., Miller, K.G., Blum, P., et al., 1994. Proc. ODP, Init. Repts., 150: College Station, TX (Ocean Drilling Program).

Myers, K.J., 1987. Onshore-outcrop gamma-ray spectrometry as a tool in sedimentological studies [Ph.D. thesis]. Univ. of London.

1989. The origin of the Lower Jurassic Cleveland Ironstone Formation of North-East England: evidence from portable gamma-ray spectrometry. In Young, T.P., and Taylor, W.E.G. (Eds.), Phanerozoic Ironstones. Geol. Soc. Spec. Publ. London, 46:221-228.

Myers, K.J., and Wignall, P.B., 1987. Understanding Jurassic organic-rich mudrocks: new concepts using gamma-ray spectrometry and palaeoecol- 
ogy: examples from the Kimmeridge Clay of Dorset and the Jet Rock of Yorkshire. $\ln$ Leggett, J.K., and Zuffa, G.G. (Eds.), Marine Clastic Sedimentology: Concepts and Case Studies: London (Graham \& Trotman), 172-189.

Odin, G.S., and Fullagar, P.D., 1988. Geological significance of the glaucony facies. In Odin, G.S. (Ed.), Green Marine Clays: Amsterdam (Elsevier), Dev. in Sedimentol. Ser., 45:295-332.

Odin, G.S., and Matter, A., 1981. Die glauconarium origine. Sedimentology, 28:611-643.

Parkinson, D.N., 1994. The sequence stratigraphy of the Lower Jurassic of Western Europe [Ph.D. thesis]. Univ. of Oxford.

, 1996. Gamma-ray spectrometry as a tool for stratigraphic interpretation: examples from the western European Lower Jurassic. In Hesselbo, S.P., and Parkinson D.N. (Eds.), Sequence Stratigraphy and its Application to British Geology. Geol. Soc. Spec. Publ. London, 103:231255.

Partington, M.A., Copestake, P., Mitchener, B.C., and Underhill, J.R., 1993a. Biostratigraphic calibration of genetic stratigraphic sequences in the Jurassic of the North Sea and adjacent areas. In Parker, J.R. (Ed.) Petroleum Geology of Northwest Europe: Proceedings of the 4th Conference. Geol. Soc. Spec. Publ. London, 371-386.

Partington, M.A., Mitchener, B.C., Milton, N.J., and Fraser, A.J., 1993b. A genetic stratigraphic sequence stratigraphy for the North Sea Late Jurassic and Early Cretaceous: stratigraphic distribution and prediction of Kimmeridgian-Late Ryazanian reservoirs in the Viking Graben and adjacent areas. In Parker, J.R. (Ed.), Petroleum Geology of Northwest Europe: Proceedings of the 4 th Conference. Geol. Soc. Spec. Publ. London, 347-370.

Poag, C.W., and Sevon, W.D., 1989. A record of Appalachian denudation in postrift Mesozoic and Cenozoic sedimentary deposits of the U.S. middle Atlantic continental margin. Geomorphology, 2:119-157.

Porrenga, D.H., 1966. Clay minerals in recent sediments of the Niger delta. Clays Clay Min. 14th Nat. Conf., 221-233.

Quirein, J.A., Gardner, J.S., and Watson, J.T., 1982. Combined natural gamma-ray spectral/litho-density measurements applied to complex lithology. SPE of AIME, 57th Annual Fall Technical Conf. and Exhibit, New Orleans, paper SPE 11143.

Rider, M.H., 1991. The Geologic Interpretation of Well Logs (2nd ed.): Caithness (Whittles Publishing).
Serra, O., 1979. Diagraphies différées; bases de l'interprétation, Tome 1. Acquisition des données diagraphiques. Bull. Cent. Rech. Explor.-Prod. Elf Aquitaine, Mem. 1.

Shipboard Scientific Party, 1994a. Site 902. In Mountain, G.S., Miller, K.G., Blum, P., et al., Proc. ODP, Init. Repts., 150: College Station, TX (Ocean Drilling Program), 63-127.

, 1994b. Site 903. In Mountain, G.S., Miller, K.G., Blum, P., et al., Proc. ODP, Init. Repts., 150: College Station, TX (Ocean Drilling Program), 129-205.

Stille, P., and Clauer, N., 1994. The process of glauconitization: chemical and isotopic evidence. Contrib. Mineral. Petrol., 117:153-263.

Swanson, V.E., 1960. Geology and geochemistry of uranium in marine black shales: a review. Geol. Surv. Prof. Pap. U.S., 356-C.

Tyson, R.V., 1996. Sequence stratigraphical interpretation of organic facies variations in marine siliciclastic systems: general principles and application to the onshore Kimmeridge Clay Formation. In Hesselbo, S.P., and Parkinson D.N. (Eds.), Sequence Stratigraphy and its Application to British Geology. Geol. Soc. Spec. Publ. London, 103:75-96.

Vail, P.R., Audemard, F., Bowman, S.A., Eisner, P.N., and Perez-Cruz, G., 1991. The stratigraphic signatures of tectonics, eustasy, and sedimentology - an overview. In Einsele, G., Ricken, W., and Seilacher, A. (Eds.), Cycles and Events in Stratigraphy: Berlin (Springer), 617-659.

Wignall, P.B., and Myers, K.J., 1988. Interpreting benthic oxygen levels in mudrocks: a new approach. Geology, 16:452-455.

Wolfe, J.A., 1978. A paleobotanical interpretation of Tertiary climates in the Northern Hemisphere. Am. Sci., 66:694-703.

1992. Climatic, floristic and vegetational changes near the Eocene/Oligocene boundary in North America. In Prothero, D.R., and Berggren, W.A. (Eds.), Eocene-Oligocene Climatic and Biotic Evolution: Princeton (Princeton Univ. Press), 421-436.

Whittaker, A., Holliday, D.W., and Penn, I.E., 1985. Geophysical logs in British stratigraphy. Spec. Rep.-Geol. Soc. London, 18.

Date of initial receipt:6 March 1995

Date of acceptance: 17 October 1995

Ms 150SR-032 